\title{
The Correlation Between Perceptions of Training Benefits with the Level of Confidence of Unjani Campus Residents in Applying Knowledge and Skills About Disaster Mitigation
}

\author{
Fransiska Ambarukmi Pontjosudargo* \\ Department of Anatomy, Faculty of Medicine \\ University of Jenderal Achmad Yani \\ Cimahi, Indonesia \\ *fransiska.ambarukmi@lecture.unjani.ac.id
}

\begin{abstract}
The disaster mitigation socialization and training program for the Unjani campus residents aims to improve the knowledge, and skills, so they understand how to behave in saving themselves, friends, and communities around in the event of a disaster. The knowledge and skills regarding disaster mitigation is an important factor that determines attitudes and behaviors that affect the preparedness ability of campus residents in the face of disasters. The purpose of this study is to assess the correlation of educational benefits and training provided, with confidence in applying the knowledge of campus citizens about disaster mitigation. A total of 56 trainees answered a questionnaire assessing the perception of benefits and confidence of participants. The data analyzed with Spearman's correlation test, with a $95 \%$ degree of confidence. Spearman's test results showed that $\mathrm{p}=0.000(\mathrm{p}<0.05)$, which meant there a significant correlation between perception of educational and training benefits with participants' confidence in applying knowledge about disaster mitigation, with an R-value of 0.710 , which indicates the strong correlation. The conclusion is, the better the perception of the benefits of education and training programs, the higher the confidence levels.
\end{abstract}

Keywords-self-confidence, training benefits, disaster mitigation, Unjani campus residents

\section{INTRODUCTION}

Indonesia is one of the countries that has areas that are vulnerable to disasters including earthquakes. In 2016, Indonesia was included in the top 5 countries with the highest number of events, which contributed $30.1 \%$ of the total disaster events in the world. One of the impacts of the earthquake was the damage to building facilities and infrastructure, including campus buildings, and offices that resulted in disruption of the learning and administration process in the campus environment [1-3]. The impact of the disaster will be more severe if the disaster occurs while the teaching and learning process is taking place on campus. Therefore, a learning environment is needed that can ensure the safety and security of school residents on standby at all times including from the threat of natural disasters [3-4].

The main campus is located in the southern part of Cimahi City, West Java. Cimahi city as one of the cities in West Java is only about 5.8 to $12 \mathrm{~km}$ from the Lembang Fault. The condition resulted in Cimahi City becoming one of the cities with the greatest risk of damage in the case of Lembang fault movement. According to a study by the Regional Disaster Management Agency (BPBD) Cimahi, based on the potential damage, Cimahi could be affected by earthquake amplification twice as large as other areas in the fault. Cimahi is in the red zone of the Sesar Lembang disaster. Therefore, efforts to socialize and foster disaster mitigation become one of the important steps that need to be encouraged, as an effort to reduce disaster risk [5].

In line with the spirit to protect children's rights to protection, safety, and survival as well as the right to a quality and sustainable primary education, education, and training on disaster mitigation need to be done, to be able to disseminate knowledge about disaster risk reduction along with safe school facilities and disaster management in schools through educators and facilitators $[4,6,7]$. The first step is to introduce a disaster mitigation system that refers to Perka BNPB No. 4 of 2012. The Government of Indonesia has established Law No. 24 of 2007 on Disaster Management, which emphasizes that Disaster Management is not only fixated on the emergency response stage but also includes the pre-disaster (preparedness) and postdisaster (recovery) stages. The law clearly states that everyone is entitled to education, training, counseling, and skills in the implementation of disaster management, both in the event of no disaster or a potential disaster situation [8-11].

The problems faced related to the availability of disaster mitigation systems in the campus environment, includes the knowledge of campus residents, especially teachers, and 
education in disaster preparedness is relatively low. Therefore, socialization and coaching, are carried out to improve participants' perception of the importance of disaster mitigation knowledge, so that participants can feel the benefits of training and have an impact to increase their confidence to implement such knowledge. Perception is a stage in which a person determines, organizes, and interprets a certain amount of information, to display in real life a picture of something that is considered meaningful [12].

Perception of usefulness is a belief in usefulness, which is the level at which a person believes that the use of technology/system will improve their performance in work. Perceived usefulness is defined as the extent to which one believes that the use of a particular system will improve its performance. From this definition, it is known that the perception of benefit is a belief about the decision-making process. If a person feels that the system is useful then he will use it. On the contrary, if a person feels that the information system is less useful then he will not use it [13]. In this case, there is an implied relationship between perception of benefit and trust. Trust is a person's belief in certainty and provision at the time of action. Confidence is a person's or individual's belief in his or her ability to continue the set of actions that lead to the desired achievement [12]. Education programs and disaster mitigation programs are conducted in addition to improving knowledge, as well as improving the perception of benefits of the importance of the program, thus increasing participants' confidence to implement their knowledge. The study in United Kingdom presented that the greater levels of social self-confidence makes a person want to act more, as a consequence of the knowledge they gain and believe to be useful [14]. This study was conducted to prove the correlation between the perception of benefits and the level of confidence of participants who attended education and disaster mitigation training.

\section{MATERIALS AND METHODS}

Socialization and simulation programs for disaster mitigation were conducted for teachers, education, and support personnel, of the Jenderal Achmad Yani University. This activity involves lecturers, students, and young doctors, collaboration with competent resource persons from the National Disaster Management Agency (BNPB). Lecturers, students, and the young doctors as well as all participants conducted activities in the form of contingency plan formulation, space simulation activities in the form of focus group discussion (FGD) supported by module books, simulation videos, and activities ended with program evaluation

After the training and simulations were conducted, 56 participants were given questionnaires to assess their perception of the benefits of training, and the trust of the participants in the basic concept of disaster management (disaster mitigation system). Participants completed an initial survey where their self confidence was measured using a modified questionnaire consist the perception about their feel that they have a good quality of knowledge after the training, about their belief in applying their knowledge in the future, and they feel capable of handling themselves in an emergency. Responses were in the form of a five point likert scale ranging from Strongly Disagree (1) to Strongly Agree (5). The data obtained were analyzed using the correlation Spearman test with a degree of trust of $95 \%$.

\section{RESULTS AND DISCUSSION}

Implementation of Disaster Mitigation Simulation Education and Training was conducted in two sessions, such as material sessions conducted online on the first day of the activity, and space simulation sessions conducted the next two days offline. In the material delivery session, participants were presented with basic disaster management materials delivered by a resource person from BNPB. This material session attended by as many as 50 people consisting of lecturers, educational and support staff, who are representatives of all work units in the campus Unjani, and the number of 10 lecturers FK Unjani who form an Internal Team, that serves to guide space simulation activities. The Simulation session was attended by 60 participants who were directly guided by speakers from BNPB. The number of 56 participants answered the questionnaire given with the results shown in Table 1.

TABLE I. DESCRIPTION OF PERCEPTION OF BENEFITS AND CONFIDENCE OF DisASTER Mitigation TRAINEES

\begin{tabular}{|l|c|c|c|c|}
\hline \multirow{2}{*}{ Perception } & \multicolumn{2}{c|}{ Benefits } & \multicolumn{2}{c|}{ Confidence } \\
\cline { 2 - 5 } & $\boldsymbol{N}$ & $\boldsymbol{\%}$ & $\boldsymbol{N}$ & $\boldsymbol{\%}$ \\
\hline Undecided & 8 & 14.28 & 8 & 14.28 \\
\hline Agree & 16 & 28.58 & 24 & 42.86 \\
\hline Strongly Agree & 32 & 57.14 & 24 & 42.86 \\
\hline Total & 56 & 100 & 56 & 100 \\
\hline
\end{tabular}

Table 1 , it showed $57.14 \%$ of participants strongly agree, $28.58 \%$ agree, and $14.28 \%$ were undecided about the benefits of disaster management education and training. There were no participants who expressed disapproval and strongly disagreed that this training activity was beneficial $(0 \%)$. In terms of the confidence of participants to practice and apply knowledge about disaster mitigation, $42.86 \%$ strongly agreed, $42.86 \%$ agree, and the remaining $14.28 \%$ were undecided. There are no participants who disagree and strongly disagree, that the education and training increase their confidence to apply knowledge about disaster mitigation.

To assess the relationship between benefit perception and the confidence level of trainees, the data obtained were analyzed with Spearman test. The results appear in Table 2.

TABLE II. SPEARMAN TEST BETWEEN BENEFIT PERCEPTION AND CONFIDENCE OF DISASTER MITIGATION TRAINEES

\begin{tabular}{|c|c|c|}
\hline Variabel & R & p Value \\
\hline Benefits \& Confidence & 0.741 & $0.000^{*}$ \\
\hline
\end{tabular}


Spearman's test shows a value of $\mathrm{p}=0.000(\mathrm{p} \leq 0.005)$ with $\mathrm{R}=0.0741$. This means that there is a significant relationship between the perception of benefits and the confidence of the trainees to implement their knowledge of disaster mitigation. The strength of the relationship between the two variables shows a moderately positive relationship (strong enough), which means the higher the perception of the benefits of the training for participants, the higher the confidence of participants in implementing their knowledge of disaster mitigation. The results of this study are in accordance with the theory that confidence is a belief in usefulness, which describes the level of a person believing that the use of technology/system will improve their performance in working/doing something. Perception of benefits can be interpreted as a person's trust in a technology/system will have a positive impact on improving its performance if useful for users of the system. The benefits of education and training to building a disaster mitigation system is the value of usefulness that will be obtained or expected by the trainees. The high perception of participants' benefits for the usefulness of the training obtained will also increase the confidence of participants to implement their knowledge and skills in building a disaster mitigation system in the campus environment [13].

The impact of the disaster in the education sector resulted in many fatalities of both students and educators, the cessation of the teaching and learning process, the destruction of school facilities and infrastructure, and the loss of school documents. The teaching and learning process is expected to continue under any circumstances and school residents have the ability and readiness to deal with disasters in schools. Therefore, it is necessary to be aware of natural disasters, especially school residents who are very vulnerable if disasters occur during school hours. Disaster Safe Education Program is important to be implemented to build a disaster preparedness culture [8-11].

Students, lecturers, and educational personnel in the campus environment, are a vulnerable part of society at the time of the disaster. The risk and vulnerability analysis team identified seven objectives of risk reduction: (1) communicate an understanding of vulnerability; (2) analyze vulnerability; (3) focus on reversing the PAR Model; (4) emphasize sustainable development; (5) improve livelihoods; (6) add recovery; and (7) extend to culture (i.e. build a safety culture). One of the efforts that can be made to reduce the risk of disaster is to conduct disaster mitigation education and training [15]. Therefore, campus residents should be accustomed to being vigilant and be trained in times of disaster. This habituation is expected to be able to build character and behaviors concerned about self-safety and the environment and be able to transmit its capabilities to those around it. Ultimately these skills have an impact on improving the quality of society. Education and training improve people's knowledge about disaster management. Training has effectiveness in improving the performance of participants. Information about emergencies is an important part of disaster mitigation efforts [6,8-10]. The National Disaster Management Agency is an institution that helps implement various programs to raise awareness of disaster management, which will make the general public more aware and always informed, as well as ready for future disasters. Through the help of various parties, it is expected that the training program can be encouraged and able to educate the community [11].

\section{CONCLUSION}

The correlation between the benefits and confidence of the participants showed a positive correlation with the strength of the relationship very strongly, meaning the better the perception of educational and training benefits, the higher the confidence level of participants in applying their knowledge of disaster mitigation. To establish disaster response and preparedness behavior, habituation needs to be done to build character and behavior of health and safety concerns themselves and the environment, so that it is expected to be able to transmit its capabilities to the surrounding community. Further hope that the knowledge and capabilities of the participants can be implemented in the campus environment, with the establishment of a disaster task force and develop an increasingly established disaster mitigation system.

\section{REFERENCES}

[1] B. Wisner, P. Blaikie, T. Cannon and I. Davis, "At Risk: natural hazard, people's vulnerability and disaster," Journal of Homeland Security and Emergency Management, vol. 2, 2005.

[2] D. Guha-Sapir, P. Hoyois, P. Wallemacq, and R. Below, Annual Disaster Statistical Review 2016: The Numbers And Trends (Center For research On The Epidemiologi of Disaster (CRED)) p 21-9, 2016

[3] A. Rahma, "Implementasi Program Pengurangan Risiko Bencana (PRB) Melalui Pendidikan Formal, Pendidikan Guru Pendidikan Anak Usia Dini, Universitas Islam Nusantara," Varia Pendidikan, vol. 30, no. 1, pp. $1-11,2018$

[4] F. Vos, J. Rodriguez, R. Below, and D. Guha-Sapir, Annual disaster statistical review 2009: The numbers and trends, pp.21-29, 2010.

[5] Y. Maulana, Kota Cimahi Masuk Zona Merah Potensi Kerusakan Sesar Lembang. detikNews. 16 Oktober 2019. [Online] Retrieved from: https://news.detik.com/berita-jawa-barat/d-4747973/kota-cimahi-masukzona-merah-potensi-kerusakan-sesar-lembang

[6] R.E. Putera, H. Nurasa, Y.S. and Sugandi, "Synergizing stakesholders in reducing risk of earthquake and tsunami disaster in most velnerable area," International Journal of Administrative Science \& Organization, vol. 23, pp. 147-155, 2016.

[7] S. Torani, P.M. Madj, S.S. Maroufi, M. Dowlati and R.A. Sheiki, "The importance of education on disasters and emergencies: a review article," J Educ Health Promot., vol. 8, pp. 85, 2019.

[8] BNPB, Peraturan Kepala Badan Nasional Penanggulangan Bencana Nomor 4 Tahun 2008 Tentang Pedoman Penyusunan Rencana Penanggulangan Bencana. Badan Nasional Penanggulangan Bencana, 2008 .

[9] BNPB, Buku Saku Tanggap Tangkas Tangguh Menghadapi bencana. Badan Nasional Penanggulangan Bencana, 2017.

[10] BNPB, Buku Pedoman Latihan Kesiapsiagaan Bencana. Membangun Kesadaran, Kewaspadaan dan Kesiapsiagaan dalam Menghadapi Bencana. Badan Nasional Penanggulangan Bencana, 2017.

[11] N. Nazli, S. Sipon, and H.M. Radzi, "Analysis of training in disaster preparedness," Procedia - Social and Behavioral Science, vol. 140, pp. 576-580, 2014. 
[12] R.M. Ibrahim and N.N.K. Moeliono, "Pengaruh Manfaat, Kepercayaan, Efikasi Diri, Kemudahan Penggunaan, Keamanan Terhadap Persepsi Konsumen Pada My Pertamina (Studi Pada Penggunaan My Pertamina Kota Bandung)," Jurnal Ilmiah Mahasiswa Ekonomi Manajemen, vol. 5, no. 2, pp. 396-413, 2020.

[13] S. Priambodo and B. Prabawani, Pengaruh Persepsi Manfaat, Persepsi Kemudahan Penggunan, Dan Persepsi Risiko Terhadap Minat
Menggunakan Layanan Uang Elektronik (Studi Kasus Pada Masyarakat Di Kota Semarang), 2019.

[14] L. Greenacre, N.M. Tung, and T. Chapman, "Self Confidence and the Ability to Influence," Academy of Marketing Studies Journal, vol. 18, pp. 169-180, 2014.

[15] J.F.S. Cyr, “At Risk: Natural Hazards, People's Vulnerability, and Disasters," Journal of Homeland Security and Emergency Management, vol. 2, pp. 1-5, 2006. 